\title{
Inclusion of wheat bran in barley-soybean meal diets with different phosphorus levels for growing-finishing pigs II. Performance and bone mineralization in growing-finishing pigs
}

\author{
EIJA HELANDER and KIRSI PARTANEN
}

\begin{abstract}
Helander, E. \& PARTANEN, K. 1994. Inclusion of wheat bran in barley-soybean meal diets with different phosphorus levels for growing-finishing pigs. II. Performance and bone mineralization in growing-finishing pigs. Agricultural Science in Finland 3: 41-48. (Department of Animal Science, FIN-00014 University of Helsinki, Finland. Present address: Eija Helander, Cultor Ltd, P.O. Box 105, FIN-00241 Helsinki, Finland.)
\end{abstract}

\begin{abstract}
The experiment was conducted to study whether wheat bran (WB) phytase could improve the availability of intrinsic phosphorus $(\mathrm{P})$ in commercial barley-soybean meal diets enough to replace the added inorganic $\mathrm{P}$ partly or completely in the diets of growing-finishing pigs $(30-100 \mathrm{~kg})$. Performance as well as certain chemical and physical parameters of the tibia and fibula bones were used as criteria for the WB phytase effect. The experiment was conducted using a $2 \times 3$ factorial arrangement. The factors were wheat bran (WB) level - either 0 (WB-) or $100 \mathrm{~g} / \mathrm{kg}(\mathrm{WB}+$ ), and phosphorus level - high (HP), medium (MP) and low (LP) corresponding to $4.33 \mathrm{~g}, 2.99 \mathrm{~g}$ and $1.64 \mathrm{~g}$ digestible $\mathrm{P}$ per a feed unit ( $\mathrm{FU}=0.7 \mathrm{~kg}$ starch equivalent), respectively. The measured digestible $P$ contents of the diets were 4.2, 4.2, 2.7, 2.5, 1.4 and $1.8 \mathrm{~g} / \mathrm{kg} \mathrm{DM}$, respectively. A content of $2.5-2.7 \mathrm{~g}$ of digestible $\mathrm{P} / \mathrm{kg} \mathrm{DM}$ in the diet proved to be sufficient for the whole growing period, but the lowest phosphorus levels led to an impaired growth rate, feed consumption and feed conversion ratio. However, after reaching $60 \mathrm{~kg}$ live weight, the pigs on LPWB- and LPWB+ diets were able to grow and utilize feed as effectively as the other pigs. WB at a level of $100 \mathrm{~g} / \mathrm{kg}$ had no significant effect on the performance, feed conversion ratio or carcass quality criteria of the pigs on any diet. WB phytase showed a positive effect on bone breaking strength on the LP diet.
\end{abstract}

Key words: phytin, phytase, growth, swine

\section{Introduction}

Pig feeds are normally supplemented with expensive inorganic phosphorus $(\mathrm{P})$, although feedstuffs of plant origin would, in principle, contain enough $\mathrm{P}$ for growing-finishing pigs. The reason for this is that plant $\mathrm{P}$ is poorly available to pigs; until now, the availability has generally been calculated to be only one third of the total P in feed ingredients of plant origin. The low availability of plant $\mathrm{P}$ is caused by phytate, the mixed potassium, magne- sium and calcium salt of phytic acid, the form in which the main part of plant $\mathrm{P}$ occurs.

Microbiologically produced phytase has been found to enhance the digestibility of $\mathrm{P}$ and the growth rate of pigs on low $\mathrm{P}$ diets in several experiments (NÄSI 1990, JONGBLOED et al. 1991, 1992, BEERS and JONGBLOED 1992, NÄSI and HELANDER 1993). Some cereal by-products like rye bran or wheat bran have a high intrinsic phytase activity (POINTILLART 1988). In a digestibility experiment conducted by POINTILLART (1991) the inclusion of 
$200 \mathrm{~g}$ rye bran per $\mathrm{kg}$ of diet increased the availability of phytate $\mathrm{P}$ and consequently improved the bone scores. JONGBLOED et al. (1991) reported that the presence of phytase enhanced the P digestibility in wheat from 0.27 to 0.50 . In the same experiment, the $\mathrm{P}$ digestibility in wheat bran almost doubled due to intrinsic phytase. In addition, the presence of wheat phytase in the diet enhanced the P digestibility of a maize-soyabean meal diet from 0.31 to 0.49 .

In Finland, wheat bran is available occasionally in abundance in feed factories and its price is reasonable. Therefore, it is tempting to add it to grower feeds for pigs. This would decrease the feed price both directly as well as indirectly due to its phytase effect, since inorganic phosphorus could then be left out of the diet. Moreover, it would be beneficial to the environment if the $\mathrm{P}$ content of pig manure could be reduced. The aim of this experiment was to evaluate whether intrinsic phytase from wheat bran could improve the availability of phytate $\mathrm{P}$ in commercial barley-soybean meal diets, thus replacing the added inorganic phosphorus partly or totally in the diets of growing pigs. Performance and certain bone parameters were used as criteria of the wheat bran phytase effect. A digestibility and balance experiment with the same feeds was conducted simultaneously (HELANDER et al. 1994).

\section{Material and methods}

A growth trial was conducted with 144 commercial crossbred pigs using a $2 \times 3$ factorial arrangement, from $30 \mathrm{~kg}$ live weight to an approximate live weight of $100 \mathrm{~kg}$ at slaughter. Four pigs were placed into each pen and six treatments were randomly allotted among the pens. Each diet was tested on three pens of barrows and three pens of gilts. The animals were group-housed and groupfed in concrete-floor pens. No bedding was used.

The feeds were pelleted $\left(65^{\circ} \mathrm{C}, 4 \mathrm{~mm}\right.$ diameter $)$ barley-soybean meal complete mixtures. The factors in diet formulation were WB inclusion ( 0 or $100 \mathrm{~g} / \mathrm{kg}$, later referred to as WB- and WB+), and three P levels - high (HP), medium (MP) and low (LP) corresponding to $4.33 \mathrm{~g}, 2.99 \mathrm{~g}$ and $1.64 \mathrm{~g}$ of digestible $\mathrm{P}$ per feed unit $(\mathrm{FU}=0.7 \mathrm{~kg}$ starch equivalent), respectively. Thus, the six diets were: HPWB-, HPWB+, MPWB-, MPWB+, LPWB- and $\mathrm{LPWB}+$. The exact composition of the experimental diets has been presented in connection with a digestibility and balance experiment (HELANDER et al. 1994). HP diets were formulated with respect to all nutrients according to the Finnish feeding recommendations (SALO et al. 1990), while the other diets were formulated correspondingly with respect to all other nutrients except $\mathrm{P}$. The inorganic $\mathrm{P}$ source was dicalciumphosphate. The calculated energy value of WB- diets was $0.99 \mathrm{FU} / \mathrm{kg}$ (SALO et al. 1990) and of WB+ diets $0.96 \mathrm{FU} / \mathrm{kg}$ and the digestible crude protein content was $144 \mathrm{~g} / \mathrm{FU}$. The calcium content was calculated to be $8.1 \mathrm{~g} / \mathrm{FU}$ in all diets. The vitamin D content was $800 \mathrm{IU} / \mathrm{kg}$ feed. Pigs were restrictively fed according to weight, using a scale from 1.7 to $2.8 \mathrm{FU} /$ pig/day. The daily feed allowances were checked once a week. The pigs were fed twice a day, and water was available ad libitum. The pigs were weighed at three-week intervals and at the end of the experiment. Feed consumption was recorded daily. Two 'runt' pigs had to be removed from treatment LPWB- in the course of the experiment because of their poor appetite and growth rate from the very beginning of the study. The most likely reason for their poor performance was their inferior quality, not the diet.

The pigs were slaughtered at an average live weight of $100 \mathrm{~kg}$. The carcass weight was recorded at slaughter. The quality grade was determined with Hennessy $\mathrm{GP}_{2}$ equipment based on the thickness of side fat and the area $\left(\mathrm{cm}^{2}\right)$ of the Longissimus dorsi muscle. In the quality grading, 9 was equal to a meat percentage over 61,8 to $59-60,7$ to $52-58$ and 6 to $<51$. The tibia and fibula bones were excised per treatment from the left hind leg of four barrows and four gilts of similar weight. The bones were frozen $\left(-18^{\circ} \mathrm{C}\right)$ to await chemical and physical analyses. The bones were weighed and the dry matter (DM), ash, Ca and P contents were determined as well as the density of the diaphyses of the fibula bones and the density and breaking strength of the tibia bones. Bone densities were determined by weighing the bones after removing soft tissues and by placing the whole bones into water and record- 
ing the quantity of water which was replaced by the bones. The weight-to-volume ratio was then calculated. The breaking strength was determined with an Instron Testing Instrument (Model 1112) by recording the amount of force applied at a constant speed of $5 \mathrm{~cm} / \mathrm{min}$ required to break a $3 \mathrm{~cm}$ piece of mid diaphysis when placed in a horizontal position on the support. In DM analysis, small pieces of fibula bones' diaphyses were dried at $105^{\circ} \mathrm{C}$ overnight. Ash percentage was determined by placing the dried bones in a $525 \mathrm{oC}$ muffle furnace for 16 hours.

The feeds were analyzed by standard methods (AOAC 1984). Amino acids were assayed with a Beckman 6300 amino acid analyzer. The ICP-AES method was used in determining the phytic acid content (PLAAMI and KUMPULAINEN 1991). In this method the sample was first burned by inductively coupled plasma and the P content was then indirectly measured by atomic emission spectrophotometry. $\mathrm{P}$ from feeds and bones was analyzed colorimetrically after dry ashing by using the vanadomolybdate procedure of TAYSSKY and SHORR (1953). The Ca contents of the feeds and bones were measured with a PerkinElmer 5100 PC atomic-absorption spectrophotometer. Phytase activity was measured as free phosphate from phytate after incubating the sample in a $0.1 \mathrm{M}$ sodium

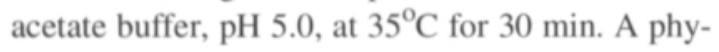
tase unit $(U)$ is defined as the amount of enzyme that liberates $1 \mu \mathrm{mol}$ of inorganic P from sodium phytate in one minute. Phytase activity was measured from the main feed ingredients and from the complete feed mixtures.

The data were analyzed by the GLM procedure of SAS (1985). The following model was used to analyze the gain and carcass data (SNEDECOR and COCHRAN 1989):

$Y_{i j k l}=\mu+T_{i}+S_{j}+\left(T^{*} S\right)_{i j}+P(T * S)_{i j k}+e_{i j k}$,

where $\mu$ is the overall mean and $\mathrm{T}, \mathrm{S}$ and $\mathrm{P}$ are the effects of treatment, sex and pen, respectively, and $\mathrm{e}_{\mathrm{ijk}}$ the residual error. A pen was considered as one experimental unit.

The feed consumption, feed conversion and bone data were analyzed using the model: $y_{i j k}=\mu+T_{i}+S_{j}+(T * S)_{i j}+e_{i j k}$, where $T$ and $S$ were as above.

The initial weight was used as a covariate in analyzing the days in the experiment and the final weight in analyzing the carcass weight, the loss at slaughter, the quality score and bone data. The degrees of freedom for treatment effects were further partitioned into single degrees of freedom by using the following orthogonal contrasts: $\mathrm{Cl}=$ WB- vs. WB+, C2 = linear effect of P level, C3 = quadratic effect of $\mathrm{P}$ level, $\mathrm{C} 4=$ interaction $\mathrm{C} 1 \mathrm{x}$ $\mathrm{C} 2, \mathrm{C} 5=$ interaction $\mathrm{C} 1 \times \mathrm{C} 3$.

\section{Results and discussion}

\section{Chemical analyses}

The analyzed chemical composition of the experimental diets as well as the P, Ca and phytase contents of the diets and feed ingredients have been presented in detail earlier by HELANDER et al. (1994). The P contents in HPWB- and HPWB+ diets were 8.2 and $8.0 \mathrm{~g} / \mathrm{kg}$ DM, in MPWB- and MPWB+ diets 6.1 and $6.2 \mathrm{~g} / \mathrm{kg} \mathrm{DM}$, and in LPWBand LPWB+ diets 4.4 and $4.9 \mathrm{~g} / \mathrm{kg}$ DM, respectively. The phytic P content of the experimental diets varied from 0.305 to 0.621 of total $P$, being always higher on WB+ diets. The digestible P content of the diets was calculated by using the digestibility coefficients determined in the previous digestibility and balance experiment (HELANDER et al. 1994). They were 4.2, 4.2, 2.7, 2.5, 1.4 and 1.8 $\mathrm{g} / \mathrm{kg} \mathrm{DM}$ for the different diets. The measured digestible P content of the LPWB+ diet was $0.4 \mathrm{~g} / \mathrm{kg}$ DM $(28 \%)$ higher than that of a LPWB- diet. This difference cannot be explained by the differences in the total $\mathrm{P}$ contents of the diets, although the LPWB+ diet contained $11 \%$ more $\mathrm{P}$ than the LPWB- diet. The difference may rather be due to WB phytase. The phytase activity of the diets was discussed in connection with the earlier digestibility and balance experiment (HELANDER et al. 1994). 
Table 1. The performance, feed consumption and carcass quality of pigs on different diets.

\begin{tabular}{|c|c|c|c|c|c|c|c|c|c|c|c|c|}
\hline Treatment $^{1}$ & HPWB- & HPWB + & MPWB- & MPWB + & LPWB- & LPWB + & $\mathrm{SEM}^{2}$ & $\mathrm{Cl}^{3}$ & $\mathrm{C} 2$ & $\mathrm{C} 3$ & $\mathrm{C} 4$ & C5 \\
\hline $\begin{array}{l}\text { No of observa- } \\
\text { tions }{ }^{4}\end{array}$ & 6 & 6 & 6 & 6 & 6 & 6 & & & & & & \\
\hline Initial weight, kg & 31.2 & 31.4 & 31.2 & 29.9 & 30.6 & 31.0 & $0.465^{5}$ & NS & NS & NS & NS & NS \\
\hline Final weight, kg & 101.0 & 101.8 & 100.2 & 99.0 & 99.4 & 98.4 & $1.37^{5}$ & NS & $*$ & NS & NS & NS \\
\hline Weight gain, kg & 69.8 & 70.4 & 69.0 & 69.1 & 68.8 & 67.4 & $1.32^{5}$ & NS & $*$ & NS & NS & NS \\
\hline Daily gain, g/d & 865 & 906 & 885 & 846 & 835 & 812 & $19.6^{5}$ & NS & $* * *$ & NS & $*$ & o \\
\hline Days in experiment & 81.3 & 78.8 & 78.4 & 81.3 & 82.6 & 83.5 & 0.86 & NS & o & NS & NS & o \\
\hline Feed, FU/pig & 194.7 & 191.5 & 188.5 & 194.0 & 201.9 & 197.3 & 3.53 & NS & o & NS & NS & NS \\
\hline FU/pig/d & 2.40 & 2.40 & 2.39 & 2.37 & 2.32 & 2.37 & 0.026 & NS & $*$ & NS & NS & NS \\
\hline $\mathrm{FCR}^{6}, \mathrm{FU} / \mathrm{kg}$ gain & 2.79 & 2.66 & 2.71 & 2.81 & 2.94 & 2.93 & 0.051 & NS & $* * *$ & NS & NS & o \\
\hline Carcass weight, $\mathrm{kg}$ & 75.3 & 75.1 & 75.9 & 75.2 & 75.4 & 74.6 & $0.36^{3}$ & NS & $*$ & NS & NS & NS \\
\hline $\begin{array}{l}\text { Loss at } \\
\text { slaughter, kg }\end{array}$ & 24.7 & 25.3 & 24.0 & 24.7 & 24.6 & 25.4 & $0.36^{3}$ & NS & NS & NS & NS & NS \\
\hline $\begin{array}{l}\text { Loss at } \\
\text { slaughter, \% }\end{array}$ & 24.7 & 24.8 & 24.1 & 24.8 & 24.6 & 25.4 & $0.36^{3}$ & NS & NS & NS & NS & NS \\
\hline Quality grade? & 8.6 & 8.4 & 8.6 & 8.7 & 8.5 & 8.8 & 0.12 & NS & NS & NS & NS & NS \\
\hline
\end{tabular}

$1 \mathrm{HP}=$ high $\mathrm{P}, \mathrm{MP}=$ medium $\mathrm{P}, \mathrm{LP}=$ low $\mathrm{P}, \mathrm{WB}-=$ no wheat bran, $\mathrm{WB}+=100 \mathrm{~g}$ wheat bran in the diet.

${ }^{2} \mathrm{SEM}=$ standard error of mean.

${ }^{3}$ Statistical significances: $\mathrm{C} 1=$ WB- vs $\mathrm{WB}+, \mathrm{C} 2=\mathrm{P}$ lin, $\mathrm{C} 3=\mathrm{P}$ quadr, $\mathrm{C} 4=\mathrm{C} 1 \times \mathrm{P}$ lin, $\mathrm{C} 5=\mathrm{C} 1 \times \mathrm{P}$ quadr

$* * *=p<.001,{ }^{* *}=p<.01,^{*}=p<.05,0<.10$ ja NS $=$ non-significant.

${ }_{4}^{4}$ Four pigs per observation except group LPWB- in which three pigs in two obs., in the rest four.

${ }^{5}$ In group LPWB-, SEM value must be multiblied by 1.05 .

${ }^{6} \mathrm{FCR}=$ feed conversion ratio $\mathrm{kg}$ feed $/ \mathrm{kg}$ gain.

${ }^{7}$ Quality grade $9=$ meat $\%>61,8=$ meat $\% 59-60,7=$ meat $\% 52-58$ and $7=$ meat $\%<51$.

\section{Performance}

The performance data of the pigs are shown in Table 1. The daily gains ranged from 812 to $906 \mathrm{~g}$, being lowest on a LPWB+ diet and highest on a HPWB+ diet. Because the protein content of the HPWB+ and MPWB+ diets was higher than targeted, the pigs on those diets got a higher proportion of protein than the other pigs. However, it is unlikely that this has affected the results because the digestible protein content of all the diets was adequate to ensure a good growth rate for all the pigs (SALO et al. 1990). All the pigs ate their rations well, and thus, got same amount of energy. The inclusion of $100 \mathrm{~g}$ of WB per $\mathrm{kg}$ of diet did not as such affect the performance of the pigs, although the digestibility of dry matter and organic matter was slightly decreased due to WB (HELANDER et al. 1994). According to CALVERT (1991), adverse ef- fects on performance occur when fibre is fed at levels above 70 to $100 \mathrm{~g}$ of the diet, but are unlikely when any fibre source is fed at levels below $50 \mathrm{~g}$ in the diet. In the present study the crude fibre content ranged from 44 to $52 \mathrm{~g} / \mathrm{kg}$. NEWTON et al. (1983) reported a slight decrease in gain and a slight increase in feed intake as the WB content of the diet increased from 0 to $100 \mathrm{~g}$ or to $200 \mathrm{~g} / \mathrm{kg}$ of diet. However, these differences were not statistically significant.

WB phytase did not show any positive effect on daily gain or feed conversion on LP diets; the growth rate of pigs on a LPWB+ diet was poorest, and the feed conversion ratio as poor as on a LPWB- diet. This was surprising, because the measured digestible P content of a LPWB+ diet was $0.4 \mathrm{~g} / \mathrm{kg}$ DM higher than of a LPWB- diet. In addition, larger quantities of the LPWB+ diet were fed to pigs because of its lower energy content. In 
an experiment with pigs from $11.8 \mathrm{~kg}$ up to $43 \mathrm{~kg}$, POINTILLART (1991) found the daily gains and feed conversion ratios to improve significantly during the last month of the trial when the diet contained $200 \mathrm{~g}$ of rye bran per $\mathrm{kg}$.

There was a linear reduction in weight gain $(\mathrm{p}<0.05)$, daily feed consumption $(\mathrm{p}<0.05)$ and feed conversion ratio $(\mathrm{p}<0.001)$ with a decreasing $P$ level in the diet. A significant interaction was found between the WB and P level of the diets with regard to daily gain $(\mathrm{p}<0.05)$. The daily gain decreased linearly on $\mathrm{WB}+$ diets $(\mathrm{p}<0.001)$ and curvilinearly on WB- diets $(\mathrm{p}<0.05)$. The examination of periodical daily gains and feed conversions revealed that pigs on LP diets were able to grow and utilize feed as well as the other pigs when they gained more weight. These results are in accordance with the earlier results of HELANDER (preliminary data). The number of days in experiment were increased quadratically on WB- diets and linearly on WB+ diets $(\mathrm{p}<0.05)$, when the $\mathrm{P}$ level of the diets decreased. Other researchers (KoCH et al. 1984, JONGBLOED 1987, DEN HARTOG et al. 1988) have also reported reduced performance, feed consumption and feed conversion ratios of pigs in LP diets. The performance is further impaired when the $\mathrm{Ca}: \mathrm{P}$ ratio of the diet is increased (KоCH et al. 1984). A $\mathrm{Ca}: \mathrm{P}$ ratio exceeding 1.3:1 on low $\mathrm{P}$ diets was found to cause a reduction in weight gain, whereas when a high dietary $\mathrm{P}$ level was provided, gains did not decline until the ratio exceeded 2.0:1 (KoCH et al. 1984). The present trial confirms these results. No significant differences in loss of weight at slaughter or quality grade of the carcasses could be attributed to the dietary P level or WB addition. Similarly, CROMWELl et al. (1970) was unable to find any significant differences in carcass traits due to the $\mathrm{P}$ content of the diets.

\section{Bones}

No visible leg weaknesses were observed in live pigs on any diet, nor were there any significant differences in tibia weights due to treatments. However, there appeared to be an interaction between dietary $\mathrm{P}$ level and WB with regard to fibula weights $(\mathrm{p}<0.1)$; the weight decreased quadratically when the P level of the diet decreased but on WB+ diets the dietary P content had no effect on fibula weight (Table 2). P-deficient diets generally have less of an effect on bone weight in growingfinishing pigs than in young pigs (CROMWELL et al. 1972). The tibia densities in this study ranged from $1.281 \mathrm{~g} / \mathrm{cm}^{3}$ on a HPWB+diet to $1.342 \mathrm{~g} / \mathrm{cm}^{3}$ on a

Table 2. Bone weights, densities, mineral contents and breaking strength on different diets.

\begin{tabular}{|c|c|c|c|c|c|c|c|c|c|c|c|c|}
\hline Treatment ${ }^{1}$ & HPWB- & HPWB + & MPWB- & MPWB + & LPWB- & LPWB + & SEM & $\mathrm{Cl}^{2}$ & $\mathrm{C} 2$ & $\mathrm{C} 3$ & $\mathrm{C} 4$ & C5 \\
\hline Tibia weight, g & 199.4 & 210.1 & 208.5 & 208.7 & 195.4 & 201.8 & 5.04 & NS & NS & NS & NS & NS \\
\hline Tibia density, $\mathrm{g} / \mathrm{cm}^{3}$ & 1.321 & 1.281 & 1.331 & 1.303 & 1.342 & 1.331 & 0.0182 & NS & o & NS & NS & NS \\
\hline Fibula weight, $\mathrm{g}$ & 31.1 & 32.5 & 32.8 & 30.4 & 29.1 & 30.2 & 1.10 & NS & o & NS & NS & o \\
\hline Fibula density, $\mathrm{g} / \mathrm{cm}^{3}$ & 1.258 & 1.302 & 1.324 & 1.296 & 1.280 & 1.208 & 0.0367 & NS & NS & NS & NS & NS \\
\hline $\begin{array}{l}\text { Ash, } \% \text { of bone } \\
\text { dry matter (fibula) }\end{array}$ & 62.9 & 62.2 & 62.7 & 60.6 & 60.4 & 60.5 & 1.62 & NS & $* *$ & NS & NS & NS \\
\hline $\begin{array}{l}\text { Calcium, g/kg } \\
\text { ash (fibula) }\end{array}$ & 373.4 & 377.6 & 381.3 & 380.6 & 371.5 & 362.5 & 2.39 & NS & $* *$ & $* * *$ & * & NS \\
\hline $\begin{array}{l}\text { Phosphorus, g/kg } \\
\text { ash (fibula) }\end{array}$ & 170.8 & 170.1 & 175.8 & 175.7 & 170.3 & 170.6 & 0.68 & NS & NS & $* * *$ & NS & NS \\
\hline $\begin{array}{l}\text { Breaking strenght, } \\
\text { kg (tibia) }\end{array}$ & 108.3 & 73.8 & 71.8 & 71.7 & 80.6 & 100.0 & 8.34 & NS & NS & $*$ & $* *$ & NS \\
\hline
\end{tabular}

1 Eight tibia and fibula bones per treatment.

2 Abbreviations and statistical significance see Table 1. 
LPWB- diet. PoINTILLART et al. (1989) recorded a density of $1.23 \mathrm{~g} / \mathrm{cm}^{3}$ for tibia and $1.22 \mathrm{~g} / \mathrm{cm}^{3}$ for the fibula bone in $60 \mathrm{~kg}$ pigs fed diets with $9 \mathrm{~g}$ of $\mathrm{Ca}$ and $5 \mathrm{~g}$ of $\mathrm{P} / \mathrm{kg}$. In the present study, the tibia density tended to increase linearly when the P content of the diet decreased. This contradicts other results of HELANDER (preliminary data). The reasons for this are difficult to explain since the diet compositions were very similar in both trials.

The ash content of the fibula bone decreased linearly with a decreasing $\mathrm{P}$ level in the diet $(\mathrm{p}<0.01)$. No change in the ash content of fibula bones due to $\mathrm{P}$ level could be found in the abovementioned earlier trial (HELANDER, preliminary results). JONGBLOED (1987) reported significantly reduced weight, volume and ash content of the radius bone with pigs on a diet which contained $6.0 \mathrm{~g} \mathrm{Ca}$ and $4.0 \mathrm{~g} \mathrm{P} / \mathrm{kg} \mathrm{DM}$ (Ca:P ratio 1.5) compared to a diet with $6.0 \mathrm{~g} \mathrm{Ca}$ and $5.6 \mathrm{~g} \mathrm{P} / \mathrm{kg} \mathrm{DM}$ (Ca:P ratio 1.07). Moreover, PIERCE et al. (1977) have reported a reduced metatarsal bone ash percentage in pigs fed low dietary levels of $P$.

The $\mathrm{P}$ contents of fibula bones decreased quadratically $(\mathrm{p}<0.001)$ when the $P$ level of the diet decreased. Thus, the $\mathrm{P}$ contents of fibulas were the highest on MP diets, the digestible Ca:digestible P ratio being closest (HELANDER et al. 1994) to the assumed ideal ratio, 1.6 (suggested by JONGBLOED 1987). In the experiment conducted by FERNÁNDEZ (1992), dietary Ca and P levels did not affect the corresponding levels in bones in pigs. There was a significant dietary WB x P level interaction in bone Ca content: on WB- diets the fibula bone calcium content decreased quadratically $(\mathrm{p}<0.01)$ while on $\mathrm{WB}+$ diets it decreased both linearly $(\mathrm{p}<0.001)$ and quadratically $(\mathrm{p}<0.01)$.

The Ca:P ratios of the bones ranged from 2.22 on a HPWB+ diet to 2.12 on a LPWB+ diet. These figures are in accordance with the preliminary results of another experiment by Helander. De WILDE and JOURQUIN (1992) reported the Ca:P ratio of the bones to be very constant and independent of the ratio in the feed. Sex had a significant effect $(\mathrm{p}<0.05)$ on bone $\mathrm{P}$ content in the present experiment: in gilts there was $171.5 \mathrm{~g}$ and in castrates $172.9 \mathrm{~g} \mathrm{P}$ per $\mathrm{kg}$ bone ash DM. In a trial conducted by Cromwell et al. (1970) gilts tended to have more ash, $\mathrm{Ca}$ and $\mathrm{P}$ in the ulna bone than barrows, although the differences were not significant.

The bone breaking strength is indicative of overall bone development, as it is affected by the degree of mineralization (quality) as well as absolute bone mass (quantity) (PIERCE et al. 1977). In the present trial, a WB x P level interaction in the breaking strength of the tibia bones was recorded $(\mathrm{p}<0.01)$; on $\mathrm{WB}+$ diets the breaking strength increased linearly $(\mathrm{p}<0.05)$ and on WB- diets it decreased both linearly $(\mathrm{p}<0.05)$ and curvilinearly $(\mathrm{p}<0.05)$ when the P level of the feed decreased. An especially great difference in bone breaking strength was recorded between treatments HPWB- and HPWB+ (108.3 vs. 73.8, respectively). The growth rate of pigs on a HPWB + diet was higher $(906 \mathrm{~g} / \mathrm{d})$ than on a HPWB- diet ( $865 \mathrm{~g} / \mathrm{d})$. A higher growth rate tends to result in a higher retention of P (JONGBLOED 1987), which is explained by the high concentration of $\mathrm{P}$ in body protein ( $9 \mathrm{~g} \mathrm{P} / \mathrm{kg}$ dry fat-free muscle). It seems that a higher growth rate leads to weaker bones in spite of a higher retention of $\mathrm{P}$. The tibia density was poorer, too, on a HPWB+ diet than on a HPWB- diet (1.281 vs $1.321 \mathrm{~g} / \mathrm{cm}^{3}$, respectively). On the LPWB+ diet, the breaking strength was much better $(100.0 \mathrm{~kg})$ than on corresponding diet without WB $(80.6 \mathrm{~kg})$. The measured digestible $\mathrm{P}$ content of a LPWB+ diet was higher $(1.8 \mathrm{~g} / \mathrm{kg} \mathrm{DM})$ than that of a LPWB- diet ( $1.4 \mathrm{~g} / \mathrm{kg}$ DM). It seems that the positive effect of WB phytase on bone strength is most evident on LP diets. Gilts tended ( $p>0.05)$ to have stronger bones than castrates; the breaking strengths were 90.2 for gilts and 78.6 for castrates. In another experiment by Helander (preliminary results), a similar sex effect was found.

In conclusion, $100 \mathrm{~g}$ of WB/kg in barley-soybean meal based diets was not found to have any effect on the growth rate, feed conversion ratio or carcass quality criteria in growing-finishing pigs. Thus, 100 $\mathrm{g}$ of $\mathrm{WB} / \mathrm{kg}$ can be added to grower feeds of pigs to reduce feed raw material costs. 6.1-6.2 $\mathrm{g}$ total $\mathrm{P} / \mathrm{kg}$ DM (2.5-2.7 g digestible P/kg DM) in the diet was enough for slaughter pigs from $30 \mathrm{~kg}$ to $100 \mathrm{~kg}$ live weight, while 4.4-4.9 g P (1.4-1.8 g digestible P) per $\mathrm{kg}$ DM led to impaired overall growth rate, feed consumption and feed conversion. The P supply was necessary especially during the grower phases 
(30-60 kg) but finishing pigs were able to grow well without any additional P supply. No signs of leg weaknesses were observed in live pigs on any diet. WB phytase seemed to have a positive effect on bone breaking strength on a low $\mathrm{P}$ diet, but it appears that the use of $100 \mathrm{~g}$ of WB/ $\mathrm{kg}$ feed due to its phytase effect in order to improve the performance and feed conversion of growing-finishing pigs on low $\mathrm{P}$ diets is not of any great value.
Acknowledgements. The authors wish to thank Mr. K. Andersson, who cared for the experimental animals, and Associate Prof. Matti Näsi, who gave valuable comments on the manuscript. The financial support provided by the Academy of Finland and Suomen Rehu Ltd. is gratefully acknowledged.

\section{References}

AOAC 1984. Official methods of analysis. 1141 p. Association of Official Analytical Chemists, Inc., Arlington. Virginia.

BeERs, S. \& JongBloed, A.W. 1992. Effect of supplementary Aspergillus niger phytase in the diets for piglets on their performance and apparent digestibility of phosphorus. Animal Production 55: 425-430.

CAlvert, C.C. 1991. Fiber utilization by swine. In: Miller, E.R. et al. (eds.). Swine nutrition, 1th ed. ButterworthHeinemann, Stoneham, MA, USA. p. 285-286.

Cromwell, G.L., Hays, V.W., Chaney, C.H., Overfield, J.R. 1970. Effects of dietary calcium and phosphorus on performance and carcass, metacarpal and turbinate characteristics of swine. Journal of Animal Science 30: 519525.

-, Hays, V.W., Scherer, C.W. \& Overfield, J.R. 1972. Effects of dietary calcium and phosphorus on performance and carcass, metacarpal and turbinate characteristics of swine. Journal of Animal Science 34: 746.

Den Hartog, L.A., Tol, J.J. van der, Boer, H. \& Verstegen, M.W.A. 1988. Phosphorus digestibility of some anorganic P-sources in pigs determined by quantitative collection of the faeces and with a marker. In: Buraczewska, L. et al. (eds.). Digestive Physiology in the Pig. p. 328335.

FERNÁNDEZ, J.A. 1992. Calcium and phosphorus metabolism in growing pigs studied by the balance technique and simultaneous radio-calcium and radio-phosphorus kinetics. The Royal Veterinary and Agricultural University Department of Anatomy and Physiology. Animal Physiology Unit. Thesis. 148 p. Fredriksberg, Denmark.

Hel ander, E., Näsi, M. \& Partanen, K. 1994. Inclusion of wheat bran in barley-soybean meal diets with different phosphorus levels for growing-finishing pigs. I. Effects on nutrient digestibility and mineral balances in finishing pigs. Agricultural Science in Finland 3: 27-39.

JongBloed, A.W. 1987. Phosphorus in the feeding of pigs. Effect of diet on the absorption retention of phosphorus by growing pigs. 343 p. I.V.V.O. Rep. No. 179. Lelystad, The Netherland.

—, Everts, H. \& Kemme, P.A. 1991. Phosphorus availability and requirements in pigs. In: Haresign, W. \& Cole,
D.J.A. (eds.). Recent Advances in Animal Nutrition 1991. Butterworths, London. p. 65-80.

—, Mroz, Z. \& Kemme, P.A. 1992. The effect of supplementary Aspergillus niger phytase in diets for pigs on concentration and apparent digestibility of dry matter, total phosphorus, and phytic acid in different sections of alimentary tract. Journal of Animal Science 70: 1159-1168.

Koch, M.E., Mahan, D.C. \& CoRley, J.R. 1984. An evaluation of various biological charact eristics in assessing low phosphorus intake in weanling swine. Journal of Animal Science 59: 1546-1556.

NÄsı, M. 1990. Microbial phytase supplementation for improving availability of plant phosphorus in the diet of the growing pig. Journal of Agricultural Science in Finland 62: 435-443.

— \& Helander, E. 1993. Effects of microbial phytase supplementation and soaking of barley-soybean meal diet for improving availability of plant phosphorus for growing pigs. Acta Agriculturae Scandinavica, Section A., Animal Science 43 (in press).

Newton, G.L., Hale, O.M. \& Plank, C.O. 1983. Effect of wheat bran in practical diets on mineral absorption by pigs at two ages. Canadian Journal of Animal Science 63: 399-408.

Pierce, A.B., Dolge, C.E., Bell, J.M. \& Owen, B.D. 1977. Availability of phytate phosphorus to the growing pig receiving isonitrogenous diets based on wheat or corn. Canadian Journal of Animal Science 57: 573-583.

PlaAm, S. \& Kumpulainen, J. 1991. Determination of phytic acid in cereals using ICP-AES to determine phosphorus. Journal of the Association Official Analytical Chemists 74: $32-36$.

Pointillart, A. 1988. Phytate phosphorus utilization in growing pigs. Proceedings of the 4th International Seminar on Digestive Physiology in Pigs. Polish Academy of Sciencies, Jablonna. p. 319-326.

-, Fourdin, A., Bourdeau, A. \& Thomasset, M. 1989. Phosphorus utilization and hormonal control of calcium metabolism in pigs fed phytic phosphorus diets containing normal or high calcium levels. Nutrition Report International 40: 517.

- 1991. Enhancement of phosphorus utilization in growing 
pigs fed phytate-rich diets by using rye bran. Journal of Animal Science 69: 1109-1115.

Salo, M.-L., Tuori, M. \& Kinskinen, T. 1990. Rehutaulukot ja ruokintanormit. 70 p. Yliopistopaino, Helsinki.

SAS 1985. SAS User's Guide: Statistics. 956 p. 5th Ed. SAS Institute Inc. Cary, NC, USA.

Snedecor, G.W. \& Cochran, W.G. 1989. Statistical methods. 503 p. 8th ed. Iowa University Press, Ames, Iowa.

TAYSSKY, H.H. \& ShORR, Е. 1953. A microcolometric method for the determination of inorganic phosphorus. Journal of Biological Chemistry 202: 675-685.

WILDE, R.O. de \& JourquIN, J. 1992. Estimation of digestible phosphorus requirements in growing-finishing pigs by carcass analysis. Journal of Animal Physiology and Animal Nutrition 68: 218-225.

Manuscript received September 1993

\title{
SELOSTUS
}

\section{Vehnäleseen vaikutus kasviperäisen fosforin hyväksikäyttöön lihasian ruokinnassa II. Vaikutus kasvuun, rehunkäyttöön ja luustoon}

\author{
EIJA Helander ja KIRSi PARTANEN
}

Helsingin yliopisto

Kasvatuskokeessa 144 lihasialla selvitettiin, parantaako vehnäleseen fytaasi ohrasta ja soijasta peräisin olevan fosforin hyväksikäyttöä ja voidaanko sillä näin ollen osittain tai kokonaan korvata rehuun normaalisti lisättävä epäorgaaninen fosfori. Koe suoritettiin $2 \times 3$ faktorikokeena, faktoreina vehnäleseen määrä ( 0 tai $100 \mathrm{~g} / \mathrm{kg}$ ) ja fosforitaso (korkea, keskinkertainen ja matala). Keskinkertainen fosforitaso osoittautui riittäväksi sioille koko kasvatuskaudeksi $(30-100 \mathrm{~kg})$, mutta siat, jotka söivät koko kasvatuskauden ajan rehua, jonka fosforitaso oli matala, kasvoivat heikommin ja kuluttivat enemmän rehua kasvukiloa kohti kuin muut siat. Kuitenkin nämä siat kasvoivat loppukasvatusvaiheen aikana yhtä hyvin kuin muutkin siat. Tämä viittaa siihen, että loppukasvatusrehun fosforipitoisuutta voidaan alentaa nykyisestä tasosta. Vehnälese ei vaikuttanut sikojen kasvuun, rehunhyväksikäyttöön tai teuraslaatuun. Tulosten perusteella vehnälesettä voidaan lisätä sikojen kasvatusrehuun $100 \mathrm{~g} / \mathrm{kg}$ tuotantotuloksia heikentämättä. Vaikka vehnäleseen fytaasi hieman paransikin matalafosforisella ruokinnalla olleiden sikojen sääriluun murtolujuutta, ei vehnälesettä kuitenkaan fosforin hyväksikäytön tehostamismielessä kannata rehuun lisätä. 